\title{
Spectrophotometric Determination of Barbituric Acid by Coupling with Diazotized Nitroanilines
}

\author{
Batool B. Ibraheem \\ Department of Chemistry \\ College of Science \\ Mosul University \\ batool5354@gmail.com
}

(Received 14/9/2010 ; Accepted 27/12/2010)

\begin{abstract}
A simple spectrophotometric method for the trace determination of barbituric acid (BA) has been established. The method is based on the coupling reaction of barbituric acid with diazotized nitroaniline in basic medium to form an intense yellow-water soluble and stable mono azodyes which shows maximum absorption at 418, 380, and $370 \mathrm{~nm}$ with diazotized o-, m- and p-nitroanilines, (DONA, DMNA, and DPNA), respectively. A plot of absorbance versus $B A$ concentration was linear to a certain limit, indicating that Beer's law was adhered to over the range 5-300 $\mu \mathrm{g}$ of $\mathrm{BA} / 25 \mathrm{ml}$ final volume (i.e., $0.2-12 \mathrm{ppm}$ ) with a molar absorptivity of $1.998 \times 10^{4}, 2.328 \times 10^{4}$, and $2.184 \times 10^{4} 1 \mathrm{~mol}^{-1} \mathrm{~cm}^{-1}$ for DONA, DMNA, and DPNA, respectively. Sandell sensitivity indexes were $0.0064,0.0055$, and $0.0059 \mu \mathrm{g} \mathrm{cm}^{-2}$, while the relative errors were -3.365 to $0.904 \%,-3.325$ to $0.138 \%$, and -2.053 to $2.679 \%$ for DONA, DMNA, and DPNA, respectively. The relative standard deviation (RSD) were 0.489 to $3.330,0.897$ to 2.209 and 0.059 to 3.689 for DONA, DMNA and DPNA, respectively. The optimum conditions for the color reaction, nature of dye, stability constant and the interference of variety of organic compounds had been investigated. The method has been successfully applied to the determination of barbituric acid in Tigris water river. The proposed method for the determination of barbituric acid is simple, sensitive, very low cost, has a wide analytical range and without the need for heating or solvent extraction techniques.
\end{abstract}

keywords: Azo-dye, Barbituric acid, Diazotized Nitroanilines, Spectrophotometric determination.

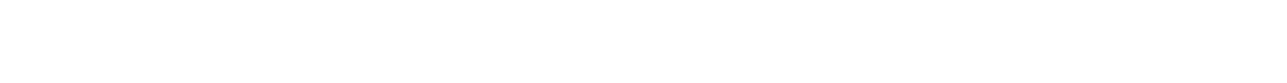

\section{|ll}

مق تثبيت طريقة بسيطة لقدير كميك متناهية في الصغر من حلمض الباربيتيوريك، تعتمد الطريقة

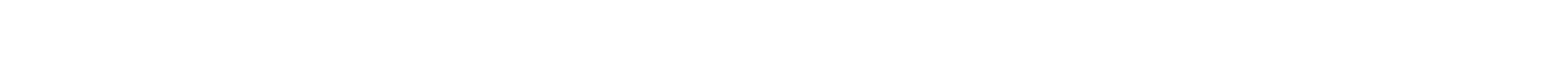
لحادية صفراء ذائبة في الماء والتي تعطي أعلى لمتصاصية عند 418 و380 و370 نانومتر للمعوضاتئت 
DMNA و DPNA وعلى التوالي. أظهر منحني الامتصاصية خطاَ مسقيماً والذي يؤكد على أنه

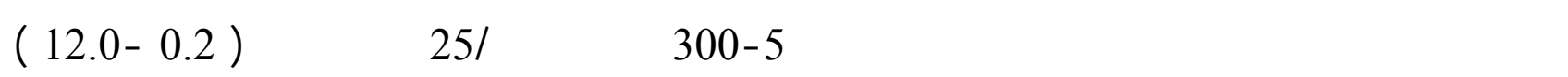

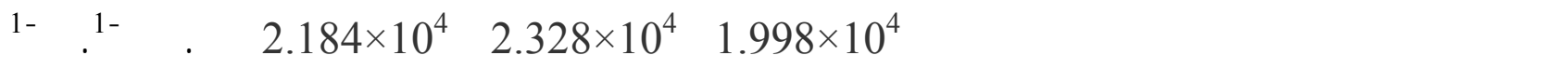
للمعوضات DONA و وDMNA و DPNA وعلى التوالي. وكلفت دلالة سانطل للمسلسية 0.0064,

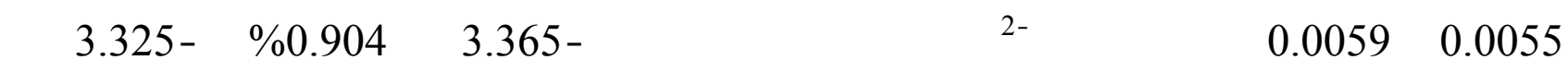

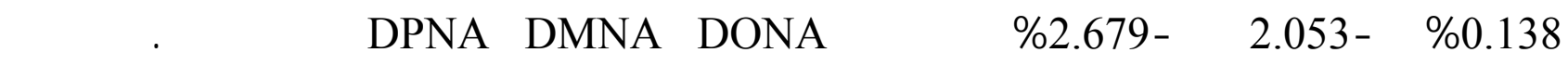
إلى أن الطريقة كلفت بسيطة وسريعة ولا تحتاج إلى التحكم في درجة الحرارة ولا ققنية المستخلاص بالمذيبت، كما وتمت درلسة الظروف المثل للفاعل وتركيب الصبغة وثابت الإنقرارية والمتدلخلات. والقد طقت الطريقة بنجاح لقدير حلمض الباربيتيورك في دماء نهر نجلة.

الكاملت الدالة: صبغة الآزو، حلمض الباربيتيوريك، ناتروانيلين، القدير الطيفي.

\section{INTRODUCTION}

Barbituric acid $\{2,4,6(1 \mathrm{H}, 3 \mathrm{H}, 5 \mathrm{H})$-pyrimidinetrione $\}$ is widely used in the preparation of barbiturates, dyes and polymerization catalysts (Hawley, 1981), pharmaceutical preparation and indicators (Acheson, 1967), textile (Brown, et al., 1970) and also been identified as an intermediate in many processes. It is well known that barbituric acid itself has no affect on the central nervous system (Wesson and Smith, 1977) however it is used as a precursor to medical barbiturates which can be lethal in excessive amounts (Matther, 1971). Therefore, the determination of trace amounts of barbituric acid is very important in studies for both biological and industrial processes. Different methods such as chromatography (Cela et al., 2000), mass spectrometry (Van Langenhove et al., 1982) capillary electrophoresis (You, 2000) infra-red spectrophotometry (Pawelczyk, et al., 1972) spectrophotometry (Medien, 1996), (Medien and Zahran, 2001) and (Bartzatt, 2002) and colorimetry (Nematollahi and Hesari, 2001) also have been reported for determination of barbituric acid. Some of these methods are time consuming and suffer from lack of selectivity or good sensitivity and/or have short linear dynamic range or have higher limit of detection and/or use reagents not commercially available.

Recently, (Nematollahi and Hesari, 2001) used controlled potential colorimetric technique for barbituric acid analysis in the range of 1-200 mmol. The method is not very sensitive and has several interferences. (Medien and Zahran, 2001) used 1,4naphthoquinone as a spectrophotometric reagent for barbituric acid determination, but the method has a high limit of determination 2.7-61.5 mg ml l- $^{-1}$ and has many interfering substances for barbiturate determination. (Bartzatt, 2002) used sodium nitrite as a suitable reagent for colorimetric analysis of barbiturate, with linear range of $18.7-225 \mathrm{mg} \mathrm{ml}^{-1}$. Therefore, the need for a fast, low cost and sensitive method is obvious, especially for routine quality control analysis. This spectrophotometric procedure is suitable for determination of barbituric acid at trace level. 


\section{EXPEREMINTAL}

\section{Apparatus}

Spectral measurements were made on a Shimadzu UV-1601 recording spectrophotometer. All the $\mathrm{pH}$ measurements were done on Elico $\mathrm{pH}$ meter (LI-10T).

\section{Reagents and Chemicals}

All chemicals used were of highest purity.

Standard barbituric acid solution (100 $\mathbf{\mu g} / \mathbf{m l})$. A $0.1000 \mathrm{~g}$ of barbituric acid dissolved in $1 \mathrm{~L}$ distilled water. This solution was prepared weekly.

Diazotized nitroanilines reagents solution, $\left(5 \times 10^{-3} \mathbf{M}\right)$. A $0.0691 \mathrm{~g}$ of o-, $\mathrm{m}-$, and $\mathrm{p}$ nitroanilines (Fluka) were dissolved in about $8 \mathrm{ml}$ of distilled water. Then $1.6 \mathrm{ml}$ of $5 \mathrm{M}$ hydrochloric acid solution was added ( the solution was heated in case of o-nitroaniline only), the clear mixture was then transferred to a 100- ml volumetric flask and cooled to 0$5^{\circ} \mathrm{C}$ in an ice bath. A $3.5 \mathrm{ml}$ of $1 \%$ of sodium nitrite $\left(\mathrm{NaNO}_{2}\right)$ solution was added and the mixture was stirred vigorously. After 5 min., the solution was made up to volume in $100-\mathrm{ml}$ volumetric flask with cold distilled water. The solution was kept in a brown bottle in refrigerator and was stable for five days at least.

Hydrochloric acid solution (5 M). This solution was prepared by appropriate dilution of concentrated hydrochloric acid (Fluka) with distilled water.

$\underline{\mathrm{Na}_{2}} \underline{\mathrm{Co}_{3}} \underline{\text { solutions }} \mathbf{2 \%}$. Sodium carbonate solution were prepared by appropriate dilution of concentrated ampoule solution (Fluka) with distilled water and then transferred to a plastic bottle. The other bases (sodium hydroxide, potassium hydroxide, sodium acetate, sodium bicarbonate, sodium formate) $2 \%$ solutions were prepared by dissolving $2.0 \mathrm{~g}$ of base in $100-\mathrm{ml}$ volumetric flask with distilled water and then transferred to plastic bottle.

Surfactant solutions $\left(1 \times \mathbf{1 0}^{-3} \mathbf{M}\right)$. These solutions were prepared by dissolving $0.0365 \mathrm{~g}$ of SDS and $0.0289 \mathrm{~g}$ of CTAB each in $20 \mathrm{ml}$ distilled water and the volume was made to 100 $\mathrm{ml}$ in volumetric flask with distilled water.

Triton X-100 (1\%). This solution was prepared by completing $1.00 \mathrm{ml}$ Triton $\mathrm{X}-100$ in $100-\mathrm{ml}$ volumetric flask with distilled water.

Foreign compounds (Fluka) solutions $(100 \mu \mathrm{g} / \mathrm{ml})$. These solutions were prepared by dissolving $0.1000 \mathrm{~g}$ of the foreign compound in $1 \mathrm{~L}$ distilled water.

River water: This water taken from the middle of Tigris river in forest place in Mosul city was filtered and then 25, 50, 75 and $100 \mu \mathrm{g}$ barbituric acid were added and the recommended procedure was applied without any further treatment.

\section{Procedure}

Transfer aliquots of aqueous sample solutions containing (5-300 $\mu$ g) of barbituric acid into a series of $25-\mathrm{ml}$ calibrated flasks. To each flask, $1 \mathrm{ml}$ of reagent (DONA, DMNA, and DPNA) solutions and $1 \mathrm{ml}$ of $2 \% \mathrm{KOH}, 1 \mathrm{ml}$ of $2 \% \mathrm{CH}_{3} \mathrm{COONa}$ and $0.5 \mathrm{ml}$ of $2 \% \mathrm{NaOH}$ solutions were added, respectively. The solutions were mixed and diluted to the mark with distilled water. The absorbance of each colored solution at 418, 380, and $370 \mathrm{~nm}$ were 
measured against the reagent blank, (DONA, DMNA, and DPNA) respectively, using 1-cm cells.

For the subsequent experiments, $100 \mu \mathrm{g}$ of barbituric acid was taken and the final volumes were $25 \mathrm{ml}$.

\section{RESULTS AND DISCUSSION}

In this work, the reaction occurs in two steps: in the first step the reaction of $\mathrm{o}, \mathrm{m}$, and p-nitroaniline with sodium nitrite occurs in an acid medium producing the diazo compound. In the second, the diazo compound in alkaline medium coupled with the barbituric acid and produced azo compound that was monitored at 418, 380 and $370 \mathrm{~nm}$.

Diazotized nitroaniline reagents had been selected in this study for the following reasons: (1) the strongest diazonium electrophile ever used . (2) the strongest color observed in its azo dye production. (3) the solution of the diazotized nitroaniline reagents are stable for long time ( $>1$ week) if kept in cold and dark conditions, and (4) the color of the diazotized reagents are faint yellow thus giving lower blank values (Al-Abbasi, 2009, AlKass and Younis, 2004, Bashir and Mansour, 2007 , Othman, 2004, Rahim et al., 1986, )

The reaction involving diazotized nitroanilines as the chromogenic reagent for the determination of barbituric acid is shown below (for example DPNA). Diazotization and coupling reactions were found to be temperature dependent. Diazotization was carried out at $0-5{ }^{\circ} \mathrm{C}$ and coupling reactions was carried out at room temperature $20-25{ }^{\circ} \mathrm{C}$. However, comparison between the absorption of the three different substituent is not possible since the determination of the spectrum have been done in different $\mathrm{pHs}$. The choose of three different substituted nitroaniline reagents was in order to explore the reaction, i.e. to see whether coupling occur with all substituents $o, m, p$ - nitroanilines.
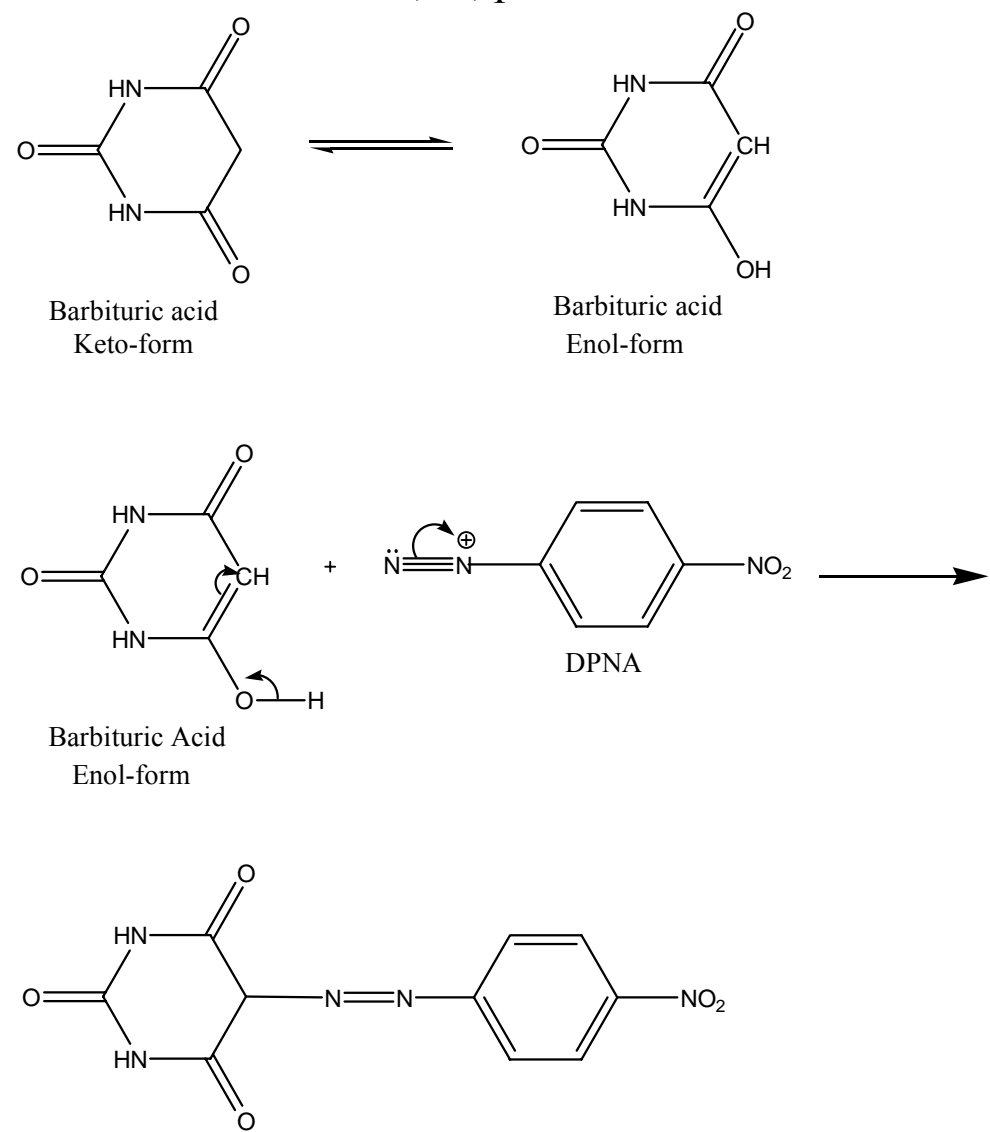


\section{Optimum Reaction Conditions :}

The effects of various parameters on the absorption intensity of the colored complex (azo-dye) were studied and the reaction conditions were optimized.

\section{Effect of Base}

To produce the colored azo-dye with barbituric acid upon coupling with diazotized substituted nitroanilines reagents, only basic medium can form the azo-dye with useful analytical properties. Therefore, different amounts $(0.5-10.0 \mathrm{ml}$ of $2 \%$ solutions) of various bases had been tried for the purpose of producing intense colored dye, and lower blank value. Ammonia solution, potassium hydroxide, sodium acetate, sodium bicarbonate and sodium hydroxide had been tried for this purpose. The experimental data had shown that potassium hydroxide solution $(1.0 \mathrm{ml}, \mathrm{pH}=12.25)$, sodium acetate solution $(1.0 \mathrm{ml}$, $\mathrm{pH}=5.00)$ and sodium hydroxide solution $(0.5 \mathrm{ml}, \mathrm{pH}=12.30)$ produced intense yellow color azo-dye with low blank value at 418,380 and $370 \mathrm{~nm}$ for DONA, DMNA and DPNA reagent respectively. Consequently, $1.0 \mathrm{ml}$ of $2 \% \mathrm{KOH}$ solution, $1.0 \mathrm{ml}$ of $2 \% \mathrm{CH}_{3} \mathrm{COONa}$ solution and $0.5 \mathrm{ml}$ of $2 \% \mathrm{NaOH}$ solution had been recommended for the subsequent experiments for DONA, DMNA and DPNA reagent, respectively.

\section{Effect of Diazotized Nitroanilines Reagents Amount}

The effect of the DNAs concentration on the color intensity of the maximum absorbance of the dye formed was studied using the proposed procedure and adding volumes from $0.5-5.0 \mathrm{ml}$ of $5.0 \times 10^{-3} \mathrm{M}$ solutions of DNAs to a series of barbituric acid solutions $(5-300 \mu \mathrm{g}$ of BA in final volume $25 \mathrm{ml})$. The results showed that a $1.0 \mathrm{ml}$ of $5.0 \times 10^{-3} \mathrm{M}$ of DNAs solution was sufficient for complete color development from both correlation as well as sensitivity points of view. Higher concentration did not enhance the absorbance further, and lower concentration did not give good results.

The absorbance of the dye formed at corresponding maximum wavelength due to varying the concentration of coupling agent were illustrated in Table 1. 
Table 1: Effect of diazotized nitroaniline reagent amount on absorbance of the dye formed.

\begin{tabular}{|c|c|c|c|c|c|c|c|c|c|c|}
\hline \multirow{2}{*}{$\begin{array}{c}\text { Reagent } \\
5 \times 10^{-3} \\
M\end{array}$} & \multirow{2}{*}{$\begin{array}{l}\mathrm{ml} \text { of } \\
\text { reagent }\end{array}$} & \multicolumn{7}{|c|}{ Absorbance, $\mu \mathrm{g} / \mathrm{ml}$ Barbituric Acid } & \multirow[b]{2}{*}{$\mathbf{R}^{2}$} & \multirow[b]{2}{*}{$\mathbf{A}_{1}$} \\
\hline & & 0.2 & 0.4 & 1.0 & 2.0 & 4.0 & 8.0 & 12.0 & & \\
\hline \multirow{7}{*}{ DONA } & 0.5 & 0.031 & 0.051 & 0.145 & 0.291 & 0.369 & 0.955 & 1.442 & 0.991 & 0.024 \\
\hline & 1.0 & 0.027 & 0.060 & 0.142 & 0.289 & 0.624 & 1.018 & 1.681 & 0.997 & 0.041 \\
\hline & 1.5 & 0.034 & 0.063 & 0.150 & 0.305 & 0.571 & 1.135 & 1.754 & 0.999 & 0.060 \\
\hline & 2.0 & 0.034 & 0.060 & 0.127 & 0.291 & 0.615 & 1.211 & 1.816 & 0.999 & 0.086 \\
\hline & 3.0 & 0.033 & 0.057 & 0.173 & 0.322 & 0.651 & 1.231 & 1.866 & 0.999 & 0.099 \\
\hline & 4.0 & 0.021 & 0.059 & 0.156 & 0.277 & 0.569 & 1.060 & 1.847 & 0.992 & 0.108 \\
\hline & 5.0 & 0.045 & 0.046 & 0.135 & 0.316 & 0.616 & 1.171 & 1.754 & 0.999 & 0.120 \\
\hline \multirow[t]{7}{*}{ DMNA } & 0.5 & 0.034 & 0.076 & 0.220 & 0.428 & 0.718 & 1.219 & 1.786 & 0.993 & 0.029 \\
\hline & 1.0 & 0.039 & 0.082 & 0.226 & 0.421 & 0.727 & 1.220 & 1.898 & 0.995 & 0.026 \\
\hline & 1.5 & 0.034 & 0.079 & 0.213 & 0.422 & 0.723 & 1.380 & 2.008 & 0.998 & 0.027 \\
\hline & 2.0 & 0.041 & 0.094 & 0.198 & 0.426 & 0.711 & 1.392 & 2.219 & 0.997 & 0.025 \\
\hline & 3.0 & 0.034 & 0.082 & 0.202 & 0.430 & 0.678 & 1.393 & 2.128 & 0.998 & 0.028 \\
\hline & 4.0 & 0.034 & 0.084 & 0.205 & 0.401 & 0.666 & 1.361 & 2.072 & 0.998 & 0.035 \\
\hline & 5.0 & 0.043 & 0.092 & 0.231 & 0.433 & 0.666 & 1.347 & 2.105 & 0.997 & 0.038 \\
\hline \multirow[t]{7}{*}{ DPNA } & 0.5 & 0.020 & 0.054 & 0.163 & 0.317 & 0.623 & 1.084 & 1.769 & 0.996 & 0.041 \\
\hline & 1.0 & 0.030 & 0.073 & 0.163 & 0.336 & 0.682 & 1.197 & 1.888 & 0.995 & 0.093 \\
\hline & 1.5 & 0.037 & 0.067 & 0.168 & 0.344 & 0.542 & 1.198 & 1.76 & 0.998 & 0.147 \\
\hline & 2.0 & 0.030 & 0.065 & 0.115 & 0.254 & 0.593 & 1.250 & 1.762 & 0.998 & 0.208 \\
\hline & 3.0 & 0.045 & 0.091 & 0.126 & 0.225 & 0.59 & 0.989 & 1.397 & 0.992 & 0.195 \\
\hline & 4.0 & 0.060 & 0.100 & 0.194 & 0.336 & 0.645 & 1.201 & 1.612 & 0.995 & 0.280 \\
\hline & 5.0 & 0.027 & 0.036 & 0.179 & 0.252 & 0.629 & 1.084 & 1.694 & 0.996 & 0.300 \\
\hline
\end{tabular}

$\mathrm{A}_{1}=$ absorbance of reagent blank against distilled water.

\section{Order of Addition.}

The order of addition for reagent $(\mathrm{ml})$ and corresponding volume of base to the sample solution $(100 \mu \mathrm{g} / 25 \mathrm{ml}$ of BA) had been examined (Table 2$)$.

Table 2: Effect of order of addition on absorbance of the dye.

\begin{tabular}{|c|c|c|c|}
\hline Reagent & $\begin{array}{c}\text { Order of } \\
\text { addition }\end{array}$ & $\mathbf{A}_{\mathbf{1}}$ & $\mathbf{A}_{\mathbf{2}}$ \\
\hline \multirow{2}{*}{ DONA } & $\mathrm{BA}+\mathrm{R}+\mathrm{B}$ & 0.612 & 0.049 \\
\cline { 2 - 4 } & $\mathrm{BA}+\mathrm{B}+\mathrm{R}$ & 0.194 & 0.040 \\
\hline \multirow{2}{*}{$\mathrm{DMNA}$} & $\mathrm{BA}+\mathrm{R}+\mathrm{B}$ & 0.701 & 0.025 \\
\cline { 2 - 4 } & $\mathrm{BA}+\mathrm{B}+\mathrm{R}$ & 0.126 & 0.020 \\
\hline \multirow{2}{*}{ DPNA } & $\mathrm{BA}+\mathrm{R}+\mathrm{B}$ & 0.672 & 0.099 \\
\cline { 2 - 4 } & $\mathrm{BA}+\mathrm{B}+\mathrm{R}$ & 0.375 & 0.030 \\
\hline
\end{tabular}

$\mathrm{A}_{1}=$ absorbance of the dye against reagent $\mathrm{R}(1 \mathrm{ml})$

$\mathrm{A}_{2}=$ absorbance of reagent against DW. 
$\mathrm{B}=$ base (recommended volume)

The order BA $+\mathrm{R}+\mathrm{B}$ for DONA, DMNA, and DPNA reagents were recommended due to their higher absorbance value since the order $\mathrm{BA}+\mathrm{B}+\mathrm{R}$ gave very low absorbance which probably due to conversion of the active diazonium salt (Ar- $N \equiv N$ ) into inactive diazohydroxide species (Ar-N=N-O ${ }^{-}$, in basic medium).

\section{Effect of Time on Formation of the Azo-Dye}

The effect of time after the addition of the reagents was evaluated for different time intervals (3-70 min). The absorbance of the azo-dye was found to be constant after $10 \mathrm{~min}$ (DONA and DMNA reagent) and after $45 \mathrm{~min}$ (DPNA reagent) and remain constant after that. The reaction proceeded very quickly at room temperature at $\left(20-25^{\circ} \mathrm{C}\right)$ and provided satisfactory results. The absorbance values were constant at this temperature, and no change was observed. Hence, heating was not needed for completion of the color development. The effect of time on the formation of the color of the azo-dye product is shown in Table 3 .

Table 3: Effect of time on the formation of the azo-dye product from BA concentration $4.0 \mu \mathrm{g} / \mathrm{ml}$.

\begin{tabular}{|c|c|c|c|}
\hline Reagent & Time, min. & $\begin{array}{c}\text { Absorbance } \\
\text { /4 } \mathbf{\mu g} \text { BA }\end{array}$ & $\mathbf{A}_{\mathbf{1}}$ \\
\hline DONA & 3 & 0.619 & 0.073 \\
\cline { 2 - 4 } & 10 & 0.621 & 0.071 \\
\cline { 2 - 4 } & 25 & 0.622 & 0.072 \\
\cline { 2 - 4 } & 45 & 0.626 & 0.070 \\
\cline { 2 - 4 } & 70 & 0.622 & 0.070 \\
\hline DMNA & 3 & 0.721 & 0.070 \\
\cline { 2 - 4 } & 10 & 0.725 & 0.074 \\
\cline { 2 - 4 } & 25 & 0.724 & 0.074 \\
\cline { 2 - 4 } & 45 & 0.722 & 0.075 \\
\cline { 2 - 4 } & 70 & 0.725 & 0.075 \\
\hline DPNA & 3 & 0.450 & 0.091 \\
\cline { 2 - 4 } & 10 & 0.577 & 0.092 \\
\cline { 2 - 4 } & 25 & 0.658 & 0.092 \\
\cline { 2 - 4 } & 45 & 0.686 & 0.092 \\
\cline { 2 - 4 } & 70 & 0.684 & 0.092 \\
\hline
\end{tabular}

$\mathrm{A}_{1}=$ absorbance of reagent against DW

\section{Effect of Surfactants}

In order to verify the importance of the electrostatic attraction in the detection of surfactant aggregates, the effects of cationic surfactant CTAB, anionic surfactant SDS and nonionic surfactant Triton X-100 was studied on the UV-visible spectra of BA. The effect of several types of surfactants on color intensity of the dye had been investigated Table 4 . 
Table 4 : Effect of surfactants on absorbance of dye formed.

\begin{tabular}{|c|c|c|c|}
\hline Reagent & Surfactant used & $\begin{array}{c}\text { Absorbance* } \\
\text { /5ml of surfactant } \\
\text { added }\end{array}$ & $\begin{array}{c}\text { Absorbance } \\
\text { without surfactant }\end{array}$ \\
\hline DONA & CTAB $\left(10^{-3} \mathrm{M}\right)$ & 0.580 & \multirow{2}{*}{0.624} \\
\hline & SDS $\left(10^{-3} \mathrm{M}\right)$ & 0.555 & \multirow{2}{*}{0.727} \\
\hline DMNA & TritonX-100(1\%) & 0.467 & \multirow{2}{*}{0.682} \\
\hline & CTAB $\left(10^{-3} \mathrm{M}\right)$ & 0.768 & \\
\hline DPNA & SDS $\left(10^{-3} \mathrm{M}\right)$ & 0.768 & 0.805 \\
\hline & TritonX-100(1\%) & 0.696 & \\
\hline & CTAB $\left(10^{-3} \mathrm{M}\right)$ & 0.700 & \\
\hline & SDS $\left(10^{-3} \mathrm{M}\right)$ & 0.713 & \\
\hline
\end{tabular}

* The concentration of BA was $100 \mu \mathrm{g} / 25 \mathrm{ml}$.

The addition of surfactants did not show a remarkable reduction of the UV-visibleabsorption intensity of the longest wavelength absorption band of the dye formed between barbituric acid and DONA in the aqueous solution. Also, there is no enhancement in case of the other two species. Therefore, we excluded the surfactants from our experiments because of the small effect of surfactants on the absorption intensity maxima of the dye formed.

\section{Absorption Spectra}

When very dilute aqueous solutions of BA and diazotized nitroaniline reagent solution are mixed in the presence of base, an intense yellow dye forms immediately. The intense dye formed shows a maximum absorption at 418,380 , and $370 \mathrm{~nm}$, in contrast to the reagent (DONA, DMNA and DPNA) blanks, which shows absorbance 0.041, 0.026, and 0.093 at the above $\lambda_{\max }$ against distilled water, respectively. 


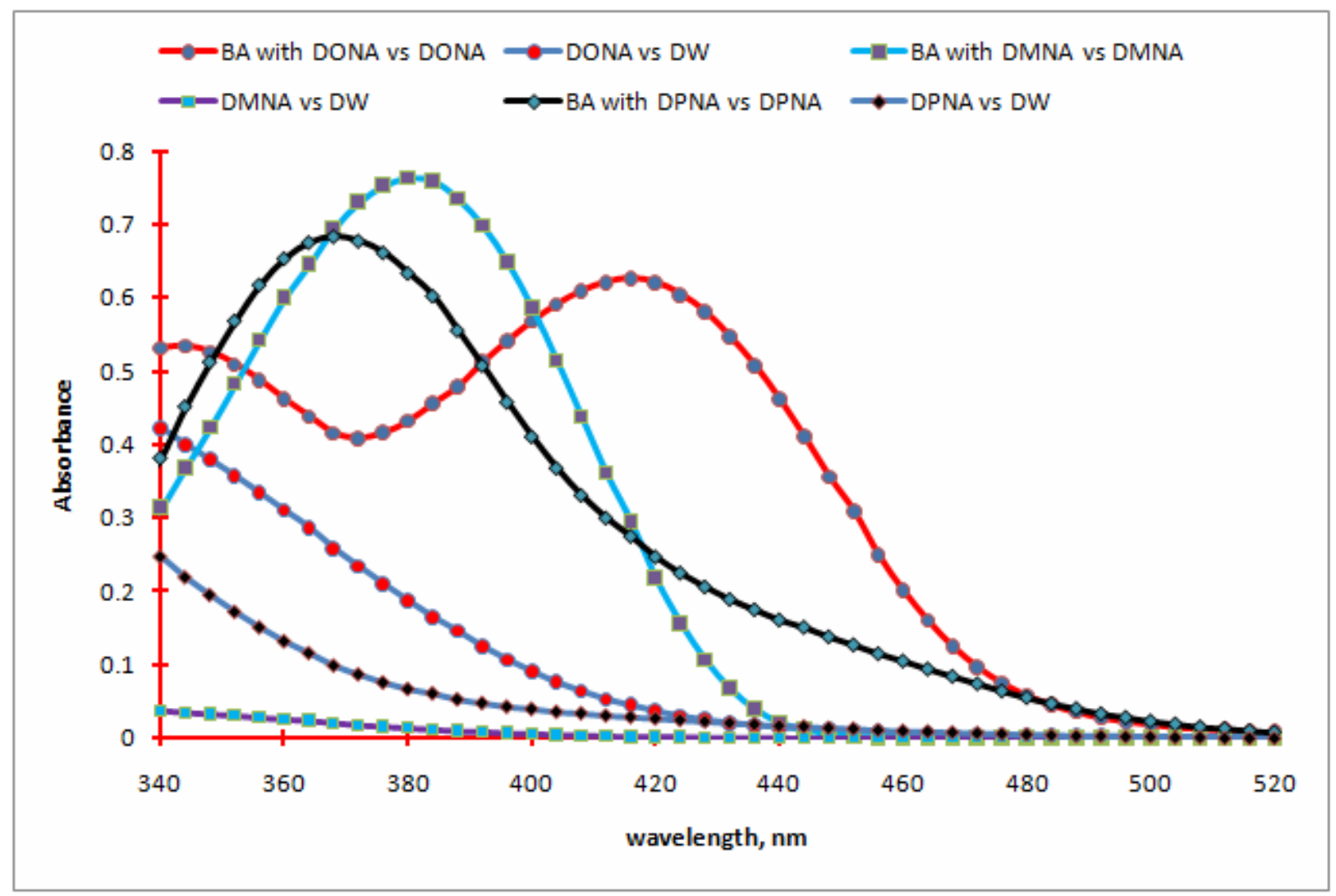

Fig. 1: Absorption spectra of $100 \mu \mathrm{g} / 25 \mathrm{ml} \mathrm{BA}$, treated as described under procedure and measured against a reagent blank; and reagent blank measured against distilled water.

The wavelength of maximum absorption of dye formed at $418 \mathrm{~nm}$ for DONA, $380 \mathrm{~nm}$ for DMNA, and $370 \mathrm{~nm}$ for DPNA was used in all subsequent experiments. Resonance effects, varying the polarity of the solvent, hydrogen-bonding and $\mathrm{pH}$ variations may explain the differences in the wavelength of maximum absorption of the individual substituted (Bashir and Mansour, 2007; Krystal, 2007).

\section{Recommended Procedure and Validity of Beer's Law}

The agreement of Beer's law was studied by measuring the absorbance values of solutions and varying barbituric acid amount. A straight-line calibration curves were obtained, indicating that Beer's Law is obeyed over the concentration range 5-300 $\mu \mathrm{g}$ of barbituric acid in $25 \mathrm{ml}$ final volume, i.e., 0.2-12 ppm as shown in Fig 2. The molar absorptivity were $1.998 \times 10^{4}, 2.328 \times 10^{4}$, and $2.184 \times 10^{4} 1 \mathrm{~mol}^{-1} \mathrm{~cm}^{-1}$ for DONA, DMNA, and DPNA, respectively, and Sandell's sensitivity index calculated as 0.0064, 0.0055, and $0.0059 \mu \mathrm{g} \mathrm{cm}^{-2}$ for DONA, DMNA, and DPNA, respectively . 

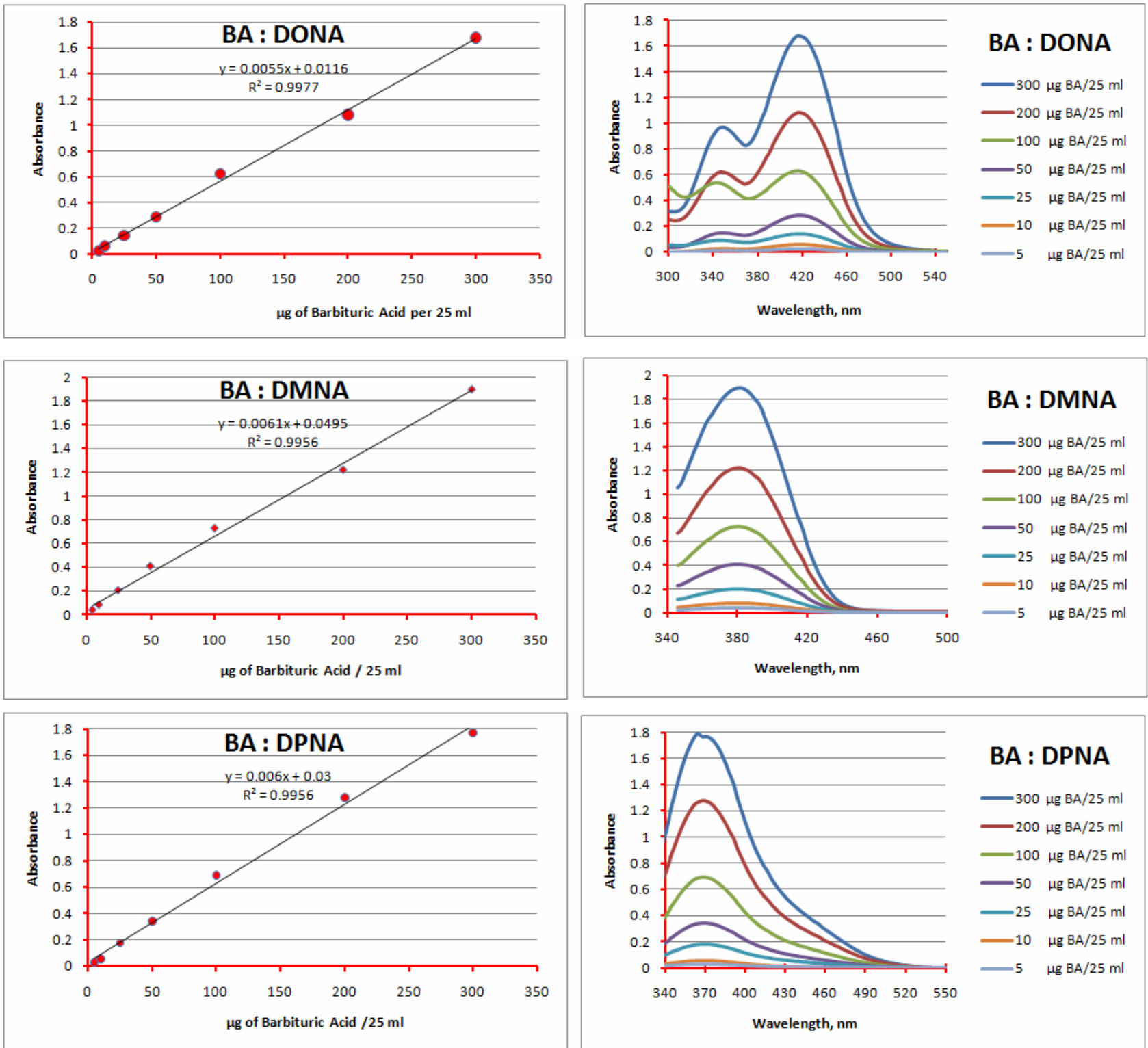

Fig 2 : Calibration curves of barbituric acid with different diazotized reagents.

\section{Nature of the Dye}

To establish the composition (ratio of barbituric acid to diazotized nitroaniline reagents) of the yellow azo dye formed, Job's method of continuous variations had been used (Hargis,1988). The resulting data reveal that the dye had been formed by the reaction of barbituric acid with diazotized nitroaniline reagent (DONA, DMNA and DPNA) in a 1:1 ratio, indicating a mono azo dye with probably of the following structures:<smiles>O=C1NC(=O)C(N=Nc2ccccc2[N+](=O)[O-])C(=O)N1</smiles>

BA:DONA<smiles>O=C1NC(=O)C(N=Nc2cccc([N+](=O)[O-])c2)C(=O)N1</smiles>

BA:DMNA<smiles>O=C1NC(=O)C(N=Nc2ccc([N+](=O)[O-])cc2)C(=O)N1</smiles>

BA:DPNA 
The apparent stability constant of azo dye in aqueous solution, under the conditions of the experimental procedure, had been calculated, and found to be $2.4126 \times 10^{4}, 2.5349 \times 10^{5}$ and $5.7968 \times 10^{5} \mathrm{M}^{-1}$, respectively.

\section{Accuracy and Precision}

In order to determine the accuracy and the precision of the method, standard solutions containing three different concentrations of BA were analyzed in five replicates. The mean results obtained are summarized in Table 5. The results indicate that the method was satisfactory.

Table 5: Accuracy and precision of the method.

\begin{tabular}{|c|c|c|c|}
\hline Reagent & Hg BA & $\begin{array}{c}\text { Relative error \% } \\
*\end{array}$ & RSD \% ** \\
\hline DONA & 2 & -1.384 & \pm 0.489 \\
\cline { 2 - 4 } & 4 & -3.365 & \pm 2.012 \\
\cline { 2 - 4 } & 8 & 0.904 & \pm 3.330 \\
\hline DMNA & 2 & -3.325 & \pm 0.897 \\
\cline { 2 - 4 } & 4 & 0.138 & \pm 1.453 \\
\cline { 2 - 4 } & 8 & -1.098 & \pm 2.209 \\
\hline DPNA & 2 & 2.679 & \pm 0.059 \\
\cline { 2 - 4 } & 4 & -2.053 & \pm 1.164 \\
\cline { 2 - 4 } & 8 & 0.042 & \pm 3.689 \\
\hline
\end{tabular}

\footnotetext{
* Average of five determinations.

** RSD Relative standard deviation.
}

\section{Study of Interferences}

The effect of interferences was studied for the proposed system, because the system was developed for the analysis of barbituric acid. Interference with variety of organic compounds was studied in the absence and presence of known amounts of variety of ions added to a solution containing $100 \mu \mathrm{g} / \mathrm{ml}$ of barbituric acid per $25 \mathrm{ml}$ final volume. Each solution was treated according to the proposed procedure. The tolerance limits of the foreign organic compounds are given in Table 6 as the amounts that caused not more than $\pm 3 \%$ changes in the values of absorbance during the determinations. These organic compounds were tolerated to a great extent without any pretreatment. 
Table 6: Effect of foreign compounds on barbituric acid determination.

\begin{tabular}{|c|c|c|c|}
\hline Reagent & Substance added & Tolerance amount added( $\mu \mathrm{g})$ & $\begin{array}{c}\text { Relative error, } \\
\%\end{array}$ \\
\hline \multirow[t]{10}{*}{ DONA } & Acetonitrile & 100 & 1.78 \\
\hline & Ethanol & 10 & -0.70 \\
\hline & Ethyl acetate & 100 & -2.92 \\
\hline & Formic acid & 100 & 0.64 \\
\hline & Malonic acid & 10 & -1.75 \\
\hline & Oxalic acid & 100 & -0.34 \\
\hline & Phenyl barbital & 100 & -0.36 \\
\hline & Sucrose & 1000 & 1.61 \\
\hline & Saccharine & 10 & -1.02 \\
\hline & Urea & 1000 & -0.72 \\
\hline \multirow[t]{10}{*}{ DMNA } & Acetonitrile & 100 & -1.24 \\
\hline & Ethanol & 10 & 0.14 \\
\hline & Ethyl acetate & 1000 & 0.00 \\
\hline & Formic acid & 100 & -1.38 \\
\hline & Malonic acid & 1000 & 0.52 \\
\hline & Oxalic acid & 100 & 0.52 \\
\hline & Phenyl barbital & 100 & -0.52 \\
\hline & Sucrose & 100 & -0.13 \\
\hline & Saccharine & 100 & -1.50 \\
\hline & Urea & 100 & -1.82 \\
\hline \multirow[t]{10}{*}{ DPNA } & Acetonitrile & 1000 & 0.48 \\
\hline & Ethanol & 1000 & 1.18 \\
\hline & Ethyl acetate & 1000 & -0.39 \\
\hline & Formic acid & 100 & 0.78 \\
\hline & Malonic acid & 10 & -0.53 \\
\hline & Oxalic acid & 1000 & -1.02 \\
\hline & Phenyl barbital & 100 & 2.01 \\
\hline & Sucrose & 1000 & -1.18 \\
\hline & Saccharine & 10 & -0.2 \\
\hline & Urea & 10 & -1.73 \\
\hline
\end{tabular}




\section{Application of the Method}

\section{Determination of Barbituric Acid in Water River}

The proposed method was successfully applied to the determination of barbituric acid in water river samples. The water samples were collected from Tigris river and were filtered before analysis. The tested water was found to be free from barbituric acid and so synthetic samples were prepared by adding known amounts of barbituric acid to the water samples. The reliability of the method to analyze real samples was checked by recovery experiments, which gave acceptable results. The recoveries are close to $100 \%$ and indicate there is no serious interference in such water samples. The results are shown in Table 7.

Table 7: Determination of (BA) added to river water samples by the recommended procedure.

\begin{tabular}{|l|c|c|c|c|}
\hline \multirow{3}{*}{ Reagent } & $\begin{array}{c}\text { Hg of BA } \\
\text { added }\end{array}$ & \multicolumn{3}{|c|}{ Recovery \% of BA per ml of river water used } \\
\cline { 2 - 5 } & 25 & $\mathbf{1 m l}$ & $\mathbf{3 m l}$ & $\mathbf{5 m l}$ \\
\hline \multirow{3}{*}{ DONA } & 101.86 & 100.31 & 104.64 \\
\cline { 2 - 5 } & 50 & 100.45 & 100.91 & 98.04 \\
\cline { 2 - 5 } & 75 & 101.73 & 99.24 & 104.35 \\
\cline { 2 - 5 } & 100 & 101.62 & 102.16 & 98.15 \\
\hline \multirow{3}{*}{ DMNA } & 25 & 99.81 & 100.93 & 100.37 \\
\cline { 2 - 5 } & 50 & 101,03 & 101.96 & 101.5 \\
\cline { 2 - 5 } & 75 & 100.43 & 100.87 & 100.06 \\
\cline { 2 - 5 } & 100 & 100.09 & 100.51 & 100.61 \\
\hline \multirow{3}{*}{ DPNA } & 25 & 97.63 & 95.26 & 100.24 \\
\cline { 2 - 5 } & 50 & 96.49 & 100.98 & 96.69 \\
\cline { 2 - 5 } & 75 & 100.24 & 93.70 & 104.62 \\
\cline { 2 - 5 } & 100 & 104.28 & 104.13 & \\
\hline
\end{tabular}

\section{Comparison with the other Method}

In comparison with the other methods, it had been found that proposed method seem to be more reliable for application from analytical point of view (Table 8). 
Table 8: Comparison of the methods.

\begin{tabular}{|c|c|c|c|c|}
\hline \multirow{2}{*}{$\begin{array}{l}\text { Analytical } \\
\text { parameters }\end{array}$} & \multicolumn{3}{|c|}{ Present method } & \multirow{2}{*}{$\begin{array}{l}\text { Literature method } \\
\text { (Ibraheem, 1984) }\end{array}$} \\
\hline & o-NA & m-NA & p-NA & \\
\hline $\mathrm{pH}$ & 12.25 & 5.00 & 12.35 & Basic medium \\
\hline $\begin{array}{c}\text { Temperature } \\
\left(\mathrm{C}^{\circ}\right)\end{array}$ & RT & RT & RT & RT \\
\hline $\begin{array}{l}\text { Development } \\
\text { time (min.) }\end{array}$ & 3 & 3 & 3 & 1 \\
\hline$\lambda \max (\mathrm{nm})$ & 418 & 380 & 370 & 355 \\
\hline $\begin{array}{l}\text { Medium of } \\
\text { reaction }\end{array}$ & Aqueous & Aqueous & Aqueous & Aqueous \\
\hline Reagent & DONA & DMNA & DPNA & DAA \\
\hline $\begin{array}{l}\text { Beer`s law } \\
\text { range (ppm) }\end{array}$ & $0.2-12.0$ & $0.2-12.0$ & $0.2-12.0$ & $0.4-8.0$ \\
\hline $\begin{array}{c}\text { Molar } \\
\text { absorptivity } \\
\left(1 . \mathrm{mol}^{-1} \cdot \mathrm{cm}^{-1}\right)\end{array}$ & $1.998 \times 10^{4}$ & $2.328 \times 10^{4}$ & $2.184 \times 10^{4}$ & $2.36 \times 10^{4}$ \\
\hline $\begin{array}{c}\text { Relative error } \\
(\%)\end{array}$ & $\begin{array}{c}(-3.365 \text { to } \\
0.904)\end{array}$ & $\begin{array}{c}(-3.325 \text { to } \\
0.138)\end{array}$ & $(-2.053$ to 2.679$)$ & $(-2.0$ to 0.8$)$ \\
\hline RSD (\%) & $\begin{array}{c} \pm 0.489 \text { to } \\
\pm 3.330 \\
\end{array}$ & $\begin{array}{c} \pm 0.897 \\
\text { to } \pm 2.209 \\
\end{array}$ & \pm 0.059 to \pm 3.689 & \pm 0.10 to \pm 3.30 \\
\hline $\begin{array}{c}\text { Color of the } \\
\text { dye }\end{array}$ & Yellow & Yellow & Yellow & Orange \\
\hline Nature of dye & $(1: 1)$ & $(1: 1)$ & $(1: 1)$ & $\ldots$. \\
\hline $\begin{array}{l}\text { Stability } \\
\text { constant }\end{array}$ & $2.4126 \times 10^{4}$ & $2.5349 \times 10^{5}$ & $5.7968 \times 10^{5}$ & $\cdots$ \\
\hline
\end{tabular}

RT= Room temperature.

DAA= Diazotized Anthranilic Acid

\section{CONCLUSION}

A new spectrophotometric method for the assay of micro amounts of barbituric acid in aqueous solution had been developed. The method was based on the coupling of barbituric acid with diazotized nitroanilines in basic medium. The azo-dye formed was water-soluble, stable, and shows maximum absorption at 418,380 , and $370 \mathrm{~nm}$ for DONA, DMNA, and DPNA, respectively. The proposed method for the determination of barbituric acid is simple, sensitive, very low cost, has a wide analytical range and without the need for extraction or heating. The reagent proposed has the advantage of high sensitivity and low 
absorbance of reagent blank. The developed method does not involve any stringent reaction conditions and offers the advantages of high color stability (more than 1 hour). The proposed method has been successfully applied to the determination of trace amounts of barbituric acid in Tigris water river.

\section{REFERENCES}

Acheson, R. (1967). "Introduction to Chemistry of Heterocyclic Compounds". Interscience Publishers, New York, 339 p.

Al-Abbasi, K. M. H. (2009). Spectrophotometric determination of tetracycline by azo-dye formation with diazotized p-nitroaniline -application to pharmaceutical preparations and biological fluids. Raf. J. Sci., 20(1), 61-74.

Al-Kass, S. Y. ; Younis, T. I. (2004). Spectrophotometric determination of uric acid by coupling with diazotized 4-nitroaniline reagent. Raf. J. Sci., 15 (2), 174-183.

Bartzatt, R. (2002). Determination of barbituric acid, utilizing a rapid and simple colorimetric assay. J. Pharm. Biomed. Anal. 29, 909-915.

Bashir, W. A. ; Mansour, S. S., (2007). Spectrophotometric assay of thymol in various samples by coupling with diazotized p-nitroaniline, Raf. J. Sci., 18(1), 28-37.

Brown, D.; Evans, R.; Batterham, T. (1970). "The Pyrimidines Supplements", Wiley Interscience, New York, 199 p.

Cela, R.; García-Borregón, P. F.; Lores, M. (2000). Analysis of barbiturates by micro-high--performance liquid chromatography with post-column photochemical derivatization . J. Chromatogr. A, 870, 39-44.

Hawley, G.G. (1981). The Condensed Chemical Dictionary, 10th edn., D. Van Company, New York, 104 p.

Ibraheem, B.B. (1984). Spectrophotometric determination of some organic and inorganic compound in aqueous solution. M Sc. Thesis, Dept. of Chem., College of Sci., University of Mosul, Mosul, Iraq.

Krystal, L. P.; Mark, G. V.; Jacob Boucher, A.; Chen, W.; Kaitlyn, R. S.; Merritt, M. S.; Brittany, G. C.; Bridget, L. B.; Steven, E. B.; Donald, A. P. (2007). Surfaceenhanced vibrational and TPD study of nitroaniline isomers. J. Phys. Chem. C, 111 33, 12352-12360

Matther, H. (1971). "Acute Barbiturate Poisoning", Excerpta Medica, Amsterdam, 14 p. Medien , H. A. A. (1996). New method for spectrophotometric determination of quinones and barbituric acid through their reaction. A Kinetic Study, Spectrochem. Acta Part A, 52, 1679-1684.

Medien, H. A. A.; Zahran, A. A. (2001). Spectrophotometric kinetic and determination of quinones and barbiturates. Spectrochim. Acta Part A, 57, 2505-2511.

Nematollahi, D.; Hesari, M. (2001). Electrochemical study of iodide in the presence of barbituric acid. application to colorimetric titration of barbituric acid, Microchem. J. 70, 7-11.

Othman, N. S. (2004). Spectrophotometric determination of indole by coupling with diazotized p-nitroaniline -application to waters, Raf. J. Sci. 15, 16-22.

Pawelczyk, E.; Marciniec, B.; Pluta, I. (1972). Application of iinfra-red spectrometry to quantitative assays of drugs. i. infra-red spectrometric determination of some barbituric acid derivatives. Acta Pol. Parm., 29, 382-390. 
Rahim, S. A.; Ismail, N. D. ; Bashir, W. A. (1986). Spectrophotometric determination of aniline in aqueous solution by azo-dye formation with diazotized p-nitroaniline, Mikrochem. Acta, (Wien) III, 417-423.

Van Langenhove, A.; Biller, J. E.; Biemann, K.; Browen, T. R. (1982). "Simultaneous determination of phenobarbital and p-hydroxyphenobarbital and their stable isotope labeled analogs by gas chromatography mass spectrometry", Biomed. Mass Spectrom., 9, 201.

Wesson, W.; Smith, D. (1977). "Barbiturates: Their Use, Misuse, and Abuse", Science Press, New York, $18 \mathrm{p}$.

You, T.; Yang, X.; Wang, E. (2000). Determination of barbituric acid and 2-thiobarbituric acid with end-column electrochemical detection by capillary electrophoresis, Talanta, 51, 1213-1218. 